\title{
Cikkismertetés: A káros gyermekkori élmények hosszú távú egészségügyi következményei és ezek költségei Európában és Észak-Amerikában
}

\author{
Article review: Life course health consequences and associated costs of \\ Adverse Childhood Experiences across Europe and North America
}

\begin{abstract}
Ismertető: $\quad$ Devosa Iván
Ismertetett cikk: Bellis, M. A., Hughes, K., Ford, K., Rodriguez, G. R., Sethi, D., \& Passmore, J. (2019). Life course health consequences and associated annual costs of adverse childhood experiences across Europe and North America: a systematic review and meta-analysis. The Lancet Public Health, 4(10), e517-e528. doi: 10.1016/S2468-2667(19)30145-8

Kulcsszavak: $\quad$ egészségügyi következmények; káros gyermekkori élmények; költségek; áttekintő közlemény; metaanalízis

Keywords: $\quad$ health consequences; adverse childhood experiences; costs; systematic review; meta-analysis
\end{abstract}

Beküldve: 2021. 03. 26., doi: 10.24365/ef.v62i3.6168

\section{HÁTTÉR}

A káros gyermekkori élmények (Adverse Childhood Experiences, $A C E)$ és az akár egész életen át tartó rossz egészségi állapot közötti összefüggéseket egyre több tanulmány dolgozza fel. Jelen publikációban a kutatók célja volt, hogy kiszámítsák az egy vagy több ACE jelenlétének tulajdonítható kockázati tényezők és az egészségkárosodás arányát, illetve az ezekhez kapcsolódó költségeket. Az ACE-ek a gyermekeket érintő legintenzívebb stresszforrásokat jelentik, melyeket 10 pontos skálán mérnek: fizikai, érzelmi és szexuális bántalmazás, fizikai és érzelmi elhanyagolás, szerhasználó vagy mentális zavarban szenvedő családtaggal való együttélés, családon belüli kriminalitás, a gyermek bántalmazás szemtanúja, valamint a szülők különélése vagy válása. $\mathrm{Az}$ egészségkárosodások, illetve a tanulási nehézségek mellett az ACE-ek az egészségkárosító magatartásformák (többek között a dohányzás, a túlzott alkoholfogyasztás és a drogfogyasztás) kialakulásának magasabb kockázatát is eredményezik. Ugyancsak az ACE-ek állhatnak egyes mentális zavarok, valamint daganatos, illetve szív- és érrendszeri betegségek megjelenése mögött. Az ACE-ek a mentális egészségre gyakorolt káros hatásokon, valamint az egészségkárosító magatartásformák kialakulásán keresztül eredményezhetik a krónikus betegségek kialakulását.

\section{MÓDSZER}

A szerzők metaanalízisük készítése során azon kutatásokat elemezték, melyek felhasznált módszereikben az ACE-szel rendelkező egyének kockázati adatait hasonlították össze az ACE nélküli betegek adataival. A szerzők ugyanebben a témában áttekintő közleményt is írtak, de ennek bemutatására jelen szemle nem terjed ki. A kutatók hat elektronikus adatbázisban (MEDLINE, CINAHL, PsycINFO, Applied Social Sciences Index and Abstracts, Criminal Justice Databases és az Education Resources Information Center) kerestek olyan kvantitatív tanulmányokat, amelyek 1990. január 1. és 2018. július 11. között jelentek meg. További kritérium volt, hogy a tanulmányok vizsgálják az ACE-ek számával összefüggésben a felnőttek rossz egészségi állapotának okait is - mindezt az egészséggel kapcsolatos viselkedésmintákhoz köthetően.

Jelen tanulmány szerzői olyan, felnőtteken végzett vizsgálatokat válogattak be kutatásukba, ahol a vizsgálati populációkban: 1. nem volt magas az ACE kockázata, 2. a minta mérete legalább 1000 fő volt, 3. amelyek ACE-ek gyakoriságát is 
feltüntették. Kiszámították az összesített relatív kockázat ${ }^{1}$ értékét az ACE-ekkel összefüggő kockázati tényezők (túlzott alkoholfogyasztás, tiltott kábítószer-fogyasztás, dohányzás és elhízás) és a rossz egészségi állapot (daganatos betegségek, cukorbetegség, szív- és érrendszeri betegségek, légzőszervi betegségek, szorongás és depreszszió) felhasználásával. A kutatók ugyancsak kiszámították a relatív kockázat értékét az ACEekhez köthető egészségkárosodással töltött korrigált életévek (disability-adjusted life-years, $D A L Y$, valamint a pénzügyi költségekhez kapcsolódó kockázati hányadok becsléséhez, továbbá a populációnak tulajdonítható frakció (population attributable fraction ${ }^{2}$ ) számításához.

\section{EREDMÉNYEK}

A szerzők az első keresés során 4387 közleményt találtak, melyek közül a címek, majd releváns cím esetén az absztraktok áttekintését követően 880 teljes szövegű cikket értékeltek. A 880 közleményből mindössze 23 felelt meg a metaanalízis összes kiválasztási kritériumának, azaz az eredetileg kiválasztott 880 publikáció csupán 2,6\%-a. [1. ábra]

\section{1. ábra: Metaaanalízis folyamata}

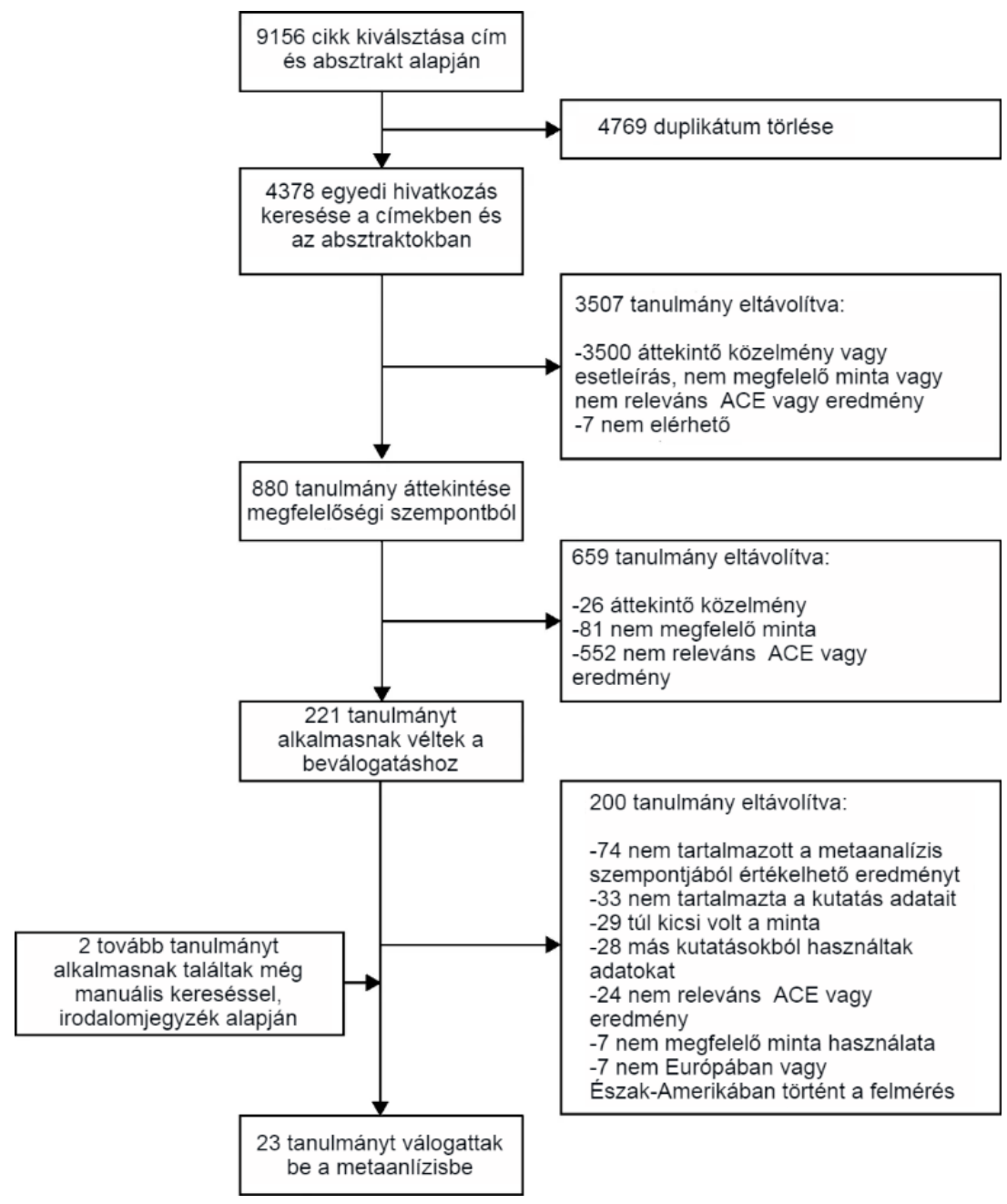

Forrás: saját ábra az eredeti alapján

\footnotetext{
${ }^{1}$ A relatív kockázatot az ökológiai, kohorsz, orvosi és intervenciós vizsgálatok adatainak statisztikai elemzésében használják, hogy megbecsüljék az expozíció (kezelések vagy kockázati tényezők) és az eredmények közötti kapcsolat erősségét. Ádány R. (2011). Megelőző orvostan és népegészségtan. https://regi.tankonyvtar.hu/hu/tartalom/tamop425/0019 1A Megelozo orvostan es nepegeszsegtan/index.html

${ }^{2}$ A populációnak tulajdonítható frakció olyan epidemiológiai számítás, amelyet széles körben alkalmaznak a populációkban előforduló expozíció népegészségügyi hatásainak felmérésére. Mansournia M. A., Altman D. G. (2018). Population attributable fraction. BMJ 360:k757 doi: $\underline{10.1136 / \mathrm{bmj} . \mathrm{k} 757}$
} 
A kutatók megállapították, hogy az egyének 23,5\%-a (95\% Cl 18,7-28,5) egy, 18,7\% (14,7$23,2)$ pedig két vagy több pontot ért el az ACE skálán Európában (10 tanulmány adatai alapján). Észak-Amerikában az egy ponttal rendelkező egyének aránya $23,4 \%(22,0-24,8)$, míg 35,0\%-uk $(31,6-38,4)$ két vagy több pontot ért el az ACE skálán (9 vizsgálat alapján). Az illegális kábítószer-fogyasztás mindkét régióban a kiértékelt összes rizikófaktor közül az leginkább az ACE skálán elért pontokkal társult legerősebben (Európában 34,1\%; Észak-Amerikában 41,1\%). A populációnak tulajdonítható frakciók alapján mindkét régióban a legjelentősebb egészségproblémaként a mentális zavarok jelentkeztek: Észak-Amerikában a szorongásos esetek körülbelül 30\%-át, míg a depressziós esetek $40 \%$-át, Európában mindkét állapot több, mint egynegyedét tulajdonították az ACE-eknek. Az ACEekkel összefüggésbe hozható szív- és érrendszeri megbetegedések költségei lényegesen magasabbak voltak, mint az egyéb megbetegedések esetén kalkulátak, ugyanis ennek az állapotnak lényegesen magasabb a DALY-értéke, azaz több az egészségkárososdással eltöltött évek száma.
Becslések szerint az ACE-eknek tulajdonítható összes éves költség Európában 581 milliárd amerikai dollár (172 000 milliárd forint), ÉszakAmerikában pedig 748 milliárd amerikai dollár (221 000 milliárd forint), mely költségek több mint $75 \%$-a a két vagy több ACE-szel küzdő egyéneknél merült fel.

\section{KÖVETKEZTETÉSEK}

Európában és Észak-Amerikában felnőttek milliói élnek az ACE-ek örökségével. A kutatás eredményei arra utalnak, hogy az ACE-ek előfordulásának 10\%-os csökkenésével évente 3 millió DALY-t vagy 105 milliárd amerikai dollárt (mintegy 31080 milliárd forintot) takaríthatnánk meg. Számos program elérhető el már most is az ACEek megelőzésére és azok hatásainak mérséklésére: a biztonságos és gondoskodásban töltött gyermekkorra fordított kiadások gazdasági szempontból hasznosak lennének, és enyhítenék az egészségügyi ellátórendszerekre nehezedő nyomást.

\section{TANULSÁGOK A HAZAI SZAKEMBEREK SZÁMÁRA}

A hazai szakemberek számára két jelentős következtetést is le lehet vonni: az egyik, hogy egy metaanalizis készítésénél megtévesztő lehet, ha elsőre számtalan olyan cikket, forrást találunk, amely úgy tűnik, hogy elegendő lesz a kutatásunkhoz - jelen tanulmányban is 880 teljes szövegú cikkből csupán $23(2,6 \%)$ felelt meg a beválogatási kritériumoknak. Természetesen az, hogy hány tanulmányból lehet metaanalízist végezni attól is függ, mennyire jók az áttekintő tanulmányok, amelyek a metaanalízis alapjául szolgálnak és azok sok vizsgálatot foglalnak-e magukba.

A másik, hogy hazánkban is számtalan személy szenved az ACE-ek hatásaitól: valószínűsithető, hogy mintegy a társadalom negyede küszködik ennek élethosszig tartó következményeivel, hasonlóan a többi európai országhoz. Ennek társadalombiztosítás nehezedő költségei nálunk is igen jelentősek lehetnek, ezért nagyon fontosak azok a kormányzati intézkedések, amelyek a biztonságosabb és védettebb gyermekkor megteremtését tűzték ki célul ${ }^{3}$. A hazai hiányosságok ellenére számos hatékony program elérhető melyek a hazai szakpolitikák, prevenciós programok alapjául szolgálhatnak a Népegészségügy $3.0^{4}$ keretein belül is.

Információk a szerzőről:

Devosa Iván, Károli Gáspár Református Egyetem Tanítóképző Főiskolai Kar, Kecskemét, ivan@devosa.hu

\footnotetext{
3 94/2018. (V. 22.) kormányrendelet a Kormány tagjainak feladat- és hatásköréről 96.§,143/E.§ és 143/F.§

${ }^{4}$ Vitrai J. Cikkismertetés: Népegészségügy 3.0. Egészségfejlesztés, 60(4), 46-51. 2019. doi: $\underline{10.24365 / \text { ef.v60i4.500 }}$
} 